\title{
PENGARUH INSTRUMEN MONETER SYARIAH DAN EKSPOR TERHADAP PERTUMBUHAN EKONOMI DI INDONESIA
}

\author{
Wulan Asnuri*
}

\begin{abstract}
The Influence of Islamic Monetary Instruments and Exports to Economic Growth In Indonesia. The aim from this research is to analyze the effect of total financing in Islamic banking (PEM), Sharia Certificate of Bank Indonesia (SBIS) and export contribution to economic growth in Indonesia. The method that used in this study is error correction model (ECM). The result showed that in short-run SBIS gave a negative impact to econo-mic growth, otherwise the total financing and export contribution didn't have an impact to economic growth. In the long-run, total financing, SBIS, and export contribution have a negative impact to Indonesian economic growth.
\end{abstract}

Keyword: economic growth, total financing, SBIS, export contribution, ECM

Abstrak: Pengaruh Instrumen Moneter Syariah dan Ekspor terhadap Pertumbuhan Ekonomi di Indonesia. Tujuan dari penelitian ini adalah untuk menganalisis pengaruh dari total pembiayaan dalam perbankan Islam (PEM), Sertifikat Bank Indonesia Syariah (SBIS) dan kontribusi ekspor terhadap pertumbuhan ekonomi di Indonesia. Metode yang digunakan dalam penelitian ini adalah model kesalahan koreksi (ECM). Hasil penelitian menunjukkan bahwa SBIS jangka pendek memiliki dampak negatif terhadap pertumbuhan ekonomi, sebaliknya total pembiayaan dan kontribusi ekspor tidak berdampak terhadap pertumbuhan ekonomi. Dalam jangka panjang, total pembiayaan, SBIS, dan kontribusi ekspor berdampak negatif terhadap pertumbuhan ekonomi Indonesia.

Kata Kunci: pertumbuhan ekonomi, total pembiayaan, SBIS, kontribusi ekspor, ECM

Naskah diterima: 12 Januari 2013, direvisi: 10 Mei 2013, disetujui: 16 Mei 2013.

*Bank Panin Syariah, Jakarta. E-mail: wulanasnuri@gmail.com 


\section{Pendahuluan}

Sektor riil merupakan representasi dari tingkat produktivitas masyarakat suatu negara dalam menciptakan barang dan jasa. Ketika tingkat produktivitas masyarakat suatu negara mengalami peningkatan maka secara agregat akan berpengaruh pada naiknya pendapatan nasional dan pertumbuhan ekonomi suatu negara. Sektor riil juga merupakan representasi dari tingkat kesejahteraan masyarakat suatu negara karena terkait langsung dengan dunia usaha. ${ }^{1}$.

Dalam ekonomi Islam, antara sektor moneter dan sektor riil mestilah sejalan dan secara tegas moneter harus mengikuti perkembangan yang ada pada sektor riil ${ }^{2}$. Adanya sistem keuangan syariah di Indonesia saat ini terutama perbankan syariah diharapkan dapat mencerminkan visi ekonomi Islam dalam menciptakan keadilan dan terciptanya distribusi pendapatan yang merata. ${ }^{3}$

Pertumbuhan sistem keuangan syariah di Indonesia telah semakin berkembang. Hal ini dapat dilihat dari instrumen moneter syariah yang telah berkembang seiring dengan peningkatan kinerja dan tingkat kepercayaan masyarakat terhadap perbankan syariah. Terlihat dari semakin meningkatnya jumlah Dana Pihak Ketiga (DPK) dan pembiayaan yang dilakukan oleh per-bankan syariah yang pada bulan Desember 2011 mencapai Rp 115.415 Miliar dan Rp 102.655 Miliar, serta adanya instrumen moneter berupa Pasar Uang Antar-Bank Syariah (PUAS) dan Sertifikat Bank Indonesia Syariah (SBIS) untuk membantu likuiditas perbankan syariah pun. Terlebih karakter keuangan syariah memperlihatkan adanya keterkaitan langsung (direct link) antara sektor moneter dengan sektor riil. ${ }^{4}$ Sebagaimana dalam teori Endogeneous Money bahwa kebi-jakan moneter hanyalah representasi dari sektor riil. ${ }^{5}$ Implikasinya adalah bahwa tidak boleh ada dikotomi antara sektor moneter dengan sektor riil karena hakikatnya kedua sektor ini haruslah saling berkaitan. Hal ini akan lebih memperkokoh sistem keuangan syariah di Indonesia.

Bertambah kokohnya sistem keuangan syariah akan meningkatkan porsi pembiayaan yang disalurkan oleh perbankan syariah. Hal ini terlihat dari pening-

${ }^{1}$ Titman dan Warga, "Stoct Return As Predictors of Interest Rates and Inflation", dalam Journal of Financial and Quanittive Analysis, Vol. 24, 1989.

${ }^{2}$ Adiwarman A. Karim, Ekonomi Islam Suatu Kajian Ekonomi Makro, (Jakarta: The International Institute of Islamic Thought Indonesia, 2002), h. 174.

${ }^{3}$ Qurroh 'Ayuniyya, dkk., "Pengaruh Instrumen Moneter dan Konvensional", dalam Jurnal Iqtishodia Institut Pertanian Bogor, 2010, h. 6.

${ }^{4}$ Irfan Syauqi Beik, Karakter Keuangan Syariah, dalam Jurnal Iqtishodia Institut Pertanian Bogor, 2010, h. 5.

${ }^{5}$ Mausudul Alam Chouwdury, Money in Islam, (London: Routledge,1997). 
katan yang signifikan sebesar 50,6\% yaitu Rp 68.181 miliar pada tahun 2010 menjadi Rp 102.655 miliar pada tahun 2011. Peningkatan pembiayaan bank syariah yang ditujukan pada sektor riil akan berpengaruh pada jumlah barang dan jasa yang dihasilkan di masyarakat. Pada saat produktivitas masyarakat meningkat maka kemungkinan pemenuhan kebutuhan domestik akan terpenuhi dan pilihan untuk melakukan ekspor barang ke luar negeri akan meningkat pula. Dengan peningkatan angka ekspor maka akan menambah sumber pendapatan negara dari devisa yang dihasilkan yang akan digunakan untuk memenuhi kebutuhan barang modal kebutuhan dalam negeri.

Keselarasan antara sektor moneter dan sektor riil ini akan berpengaruh pada perekonomian secara agregat. Peningkatan pembiayaan bank syariah terhadap sektor riil serta peningkatan kegiatan ekspor akan mempengaruhi keseimbangan perekonomian yang akhirnya akan berpengaruh pada pertumbuhan ekonomi.

Penelitian ini bertujuan untuk menganalisis apakah terdapat pengaruh yang signifikan dari total pembiayaan bank syariah, SBIS, dan kontribusi ekspor terhadap pertumbuhan ekonomi di Indonesia dalam jangka pendek maupun jangka panjang.

Penelitian tentang pengaruh total pembiayaan bank syariah dan Sertifikat Bank Indonesia Syariah (SBIS) terhadap sektor riil yang direpresentasikan oleh Indeks Produksi Industri (IPI) telah dilakukan oleh Qurroh 'Ayuniyya dkk. (2010), hasilnya menunjukkan bahwa dalam jangka panjang pembiayaan bank syariah berpengaruh signifikan positif terhadap IPI sedangkan SBIS berpengaruh signifikan negatif terhadap IPI. Hal yang sama ditemukan oleh Mawaddah (2011), bahwa dalam jangka panjang pembiayaan mudhârabah berpengaruh signifikan positif terhadap pertumbuhan ekonomi. Disisi lain Yunie Fitriani (2011) menemukan berbeda, bahwa dalam jangka panjang pembiayaan bank syariah berpengaruh negatif terhadap pertumbuhan ekonomi.

Penelitian terkait ekspor dilakukan Asnawi (2011) yang menyatakan bahwa dalam jangka panjang ekspor akan berpengaruh negatif terhadap pertumbuhan ekonomi. Penelitian ini hanya dilakukan di provinsi Aceh saja. Lain halnya yang terjadi di beberapa negara muslim seperti yang dilakukan oleh Musleh Jawas (2008) yang menemukan bahwa ekspor berpengaruh signifikan positif terhadap pertumbuhan ekonomi.

\section{Hubungan Pembiayaan Bank Syariah terhadap Pertumbuhan Ekonomi}

Istilah pertumbuhan ekonomi digunakan untuk menggambarkan terjadinya kemajuan atau perkembangan ekonomi dalam suatu negara. Pertumbuhan 
ekonomi dapat didefiniskan sebagai perkembangan kegiatan ekonomi yang berlangsung pada suatu negara dari waktu ke waktu yang menyebabkan pendapatan nasional riil meningkat. ${ }^{6}$ Ada tiga aspek yang perlu diperhatikan terkait pertumbuhan ekonomi, yaitu proses, output per kapita, dan jangka panjang. Bahwa pertumbuhan ekonomi merupakan proses yang menggambarkan perkembangan ekonomi dari waktu ke waktu yang bersifat dinamis, output per kapita mengaitkan aspek output total dan jumlah penduduk, dan jangka panjang menunjukkan kecenderungan perubahan perekonomian dalam jangka waktu tertentu yang didorong oleh perubahan intern perekonomian. ${ }^{7}$

Pada dasarnya, yang menjadi perbedaan khas antara pembiayaan yang dilakukan oleh perbankan syariah dengan perbankan konvensional adalah bahwa akad-akad pada produk pembiayaan perbankan syariah lebih diprioritaskan untuk mendorong pergerakan sektor riil, khususnya produk kerja sama atau bagi hasil yaitu mudhârabah dan musyârakah. Pembiayaan kerja sama ini akan berdampak pada produktivitas masyarakat dalam menciptakan barang dan jasa serta meningkakan pendapatan masyarakat.

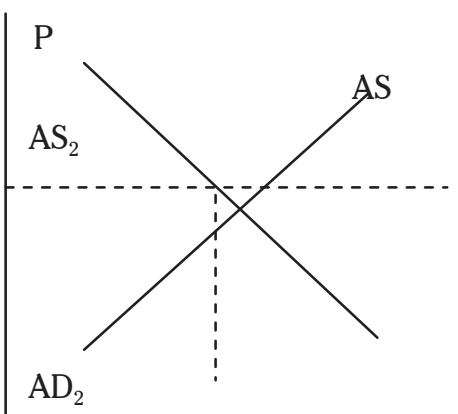

$\mathrm{AD}$

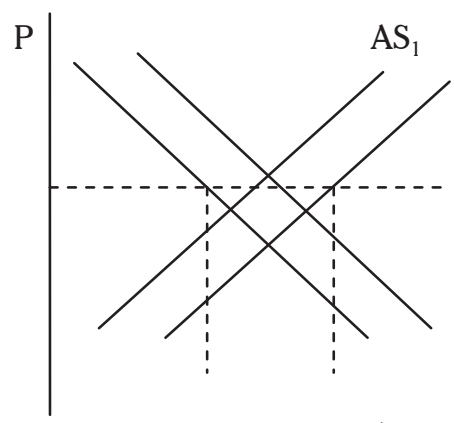

$\mathrm{AD}_{1}$

Kurva (i) $\quad$ Y

Peningkatan produktivitas masyarakat yang diakibatkan adanya pembiayaan mudhârabah dan musyarakah dalam menciptakan barang dan jasa menggambarkan Agregat Supply (AS) nasional, sedangkan peningkatan tingkat konsumsi akibat adanya peningkatan pendapatan menggambarkan Agregat Demand (AD) nasional. Kurva(i) menunjukkan kondisi perekonomian normal, sedangkan

${ }^{6}$ Asfia Murni, Ekonomika Makro, (Bandung: PT. Refika Aditama, 2006), h. 173.

${ }^{7}$ Boediono. Teori Pertumbuhan Ekonomi: Seri Sinopsis Pengantar Ilmu Ekonomi No.4. Yogyakarta: BPFE, 1993, h. 1-2. 
kurva (ii) menunjukkan kondisi perekonomian setelah adanya peningkatan produktivitas masyarakat dan tingkat konsumsi. Keseimbangan agregat ekonomi ini berlangsung secara berkelanjutan dan akhirnya akan berdampak pada peningkatan pendapatan nasional dan pertumbuhan ekonomi.

\section{Hubungan Sertifikat Bank Indonesia Syariah terhadap Pertumbuhan Ekonomi}

Sertifikat Bank Indonesia Syariah (SBIS) merupakan instrumen moneter yang disediakan oleh otoritas moneter sebagai alternatif penyimpanan kelebihan dana yang tidak tersalurkan oleh perbankan syariah ke sektro riil serta untuk membantu likuiditas perbankan syariah. Akan tetapi, penempatan dana pada instrumen SBIS menyebabkan adanya uang yang tidak berputar (idle fund) dan hal ini tidak sesuai dengan pemikiran Imam al-Ghazalî yang menyatakan bahwa uang itu seperti air, serta pemikiran Ibn Khaldûn yang menyatakan bahwa uang itu seperti darah, harus mengalir karena jika tidak maka akan terjadi masalah pada fungsi organ tubuh. Artinya, bahwa ketika terdapat uang yang tidak berputar maka perekonomian tidak dapat berjalan dengan optimal karena uang tidak dapat tersalurkan seluruhnya pada sektor riil.

Dengan demikian, ketika bank syariah lebih memilih menempatkan dananya pada instrumen SBIS maka akan mengurangi porsi pembiayaan yang disalurkan pada sektor riil dan akan mengurangi penciptaan barang dan jasa di masyarakat, menurunkan tingkat pendapatan masyarakat yang akhirnya akan menurunkan angka pertumbuhan ekonomi.

\section{Hubungan Ekspor terhadap Pertumbuhan Ekonomi}

Ekspor merupakan transakasi jual beli yang dilakukan antarnegara. Sesuai dengan teori Ibn Khaldûn bahwa ketika suatu negara melakukan kegiatan ekspor maka kebutuhan domestik akan barang dan jasa sudah terpenuhi. Ketika tingkat produksi suatu negara untuk jenis komoditi lebih tinggi daripada tingkat permintaan domestik negara tersebut, atau supply lebih besar dibanding demand, maka memungkinkan negara tersebut melakukan ekspor. Adam Smith mengatakan dalam teorinya bahwa barang yang diekspor haruslah barang yang memiliki keunggulan absolut yang merupakan kekhasan dari negara tersebut. Hal ini dapat dilakukan dengan melakukan spesialisasi. Sedangkan David Ricardo dalam theory of labour value menyatakan bahwa nilai atau harga suatu produk ditentukan oleh jumlah waktu dan jam kerja yang diperlukan untuk memproduksinya. 
Kegiatan ekspor akan meningkatkan kreativitas masyarakat dalam menciptakan barang dan jasa yang akan menjadi komoditi ekspor. Selain itu, keuntungan yang didapat dari perdagangan luar negeri ini akan dapat menambah pendapatan nasional yang nantinya akan dipergunakan untuk memenuhi barang modal kebutuhan dalam negeri. Dengan demikian, produktivitas masyarakat yang meningkat dan tersedianya barang kebutuhan dalam negeri akan meningkatkan pertumbuhan ekonomi.

\section{Metodologi}

Penelitian ini menggunakan data bulanan dari bulan Januari 2007 sampai dengan bulan Juni 2011. Data pertumbuhan ekonomi yang digunakan adalah data Produk Domestik Bruto (PDB) menurut harga konstan yang diterbitkan oleh Badan Pusat Statistik (BPS), laporan total pembiayaan bank syariah dari statistik perbankan syariah Bank Indonesia, laporan outstanding SBIS dari Bank Indonesia serta data eksppor dari kementrian perdagangan Republik Indonesia. Metode analisis yang digunakan adalah metode koreksi kesalahan atau dikenal dengan Error correction Model (ECM), yaitu suatu teknik untuk mengoreksi ketidakseimbangan jangka pendek menuju pada keseimbangan jangka panjang. ${ }^{8}$

Pertama, unit root test. Sebelum melakukan analisis regresi dengan menggunakan data time series, perlu dilakukan uji stasioneritas terhadap seluruh variabel untuk mengetahui apakah variabel-variabel tersebut stasioner atau tidak. Pengujian ini dilakukan untuk menggunakan pengujian unit root, yang bertujuan untuk mengetahui apakah data mengandung unit root atau tidak. Apabila hasil uji akar unit menunjukkan data belum stasioner pada tingkat level maka data akan diuji pada diferensiasi tingkat pertama (first difference) atau lebih hingga data menjadi stasioner.

Terdapat beberapa metode pengujian unit root, pada penelitia ini pengujian data dilakukan dengan menggunakan uji Augmented Dicky-Fuller. Apabila hasil uji Augmented Dicky-Fuller menyatakan bahwa nilai ADF statistik > 0,05 maka data stasioner sedangkan jika nilai ADF statistik < 0,05 maka data tidak stasioner.

Kedua, kointegrasi. Setelah semua data stasioner pada tingkat ordo yang sama, pengujian selanjutnya dilakukan ke uji kointegrasi. Kointegrasi berkaitan erat dengan pengujian terhadap kemungkinan adanya hubungan keseimbangan jangka panjang antar variabel-variabel ekonomi seperti yang dikehendaki oleh

${ }^{8}$ Nachrowi D. Nachrowi dan Hardius Usman, Penggunaan Teknik Ekonometri, (Jakarta: PT RajaGrafindo Persada, 2006), h. 371. 
teori ekonomi. Untuk melihat suatu model memiliki kointegrasi atau tidak, dapat dilakukan beberapa pengujian, dalam Dalam penelitian ini, untuk melihat ada atau tidaknya kointegrasi dilakukan dengan uji Engel-Granger (EG) atau uji Augmented Engel-Granger, yaitu pengujian yang dilakukan dengan memanfaatkan uji Augmented Dicky-Fuller dengan cara mengestimasi model regresi kemudian menghitung nilai residualnya. Apabila nilai residualnya stasioner maka regresi tersebut merupakan regresi kointegrasi, ${ }^{9}$ artinya terdapat hubungan jangka panjang antar variabel-variabel.

Ketiga, pendekatan error correction models (ECM). Model ECM pada dasarnya merupakan suatu konsep model ekonometri-time series yang berupaya untuk menyelaraskan kondisi jangka pendek (short run equilibrium) dengan kondisi ekuilibrium jangka panjang (long run equilibrium). Untuk menyatakan apakah model yang digunakan benar atau tidak maka koefisien error correction term (ECT) harus signifikan. Jika koefisien tidak signifikan maka model tersebut tidak cocok. ${ }^{10}$

Model ECM pada peneletian ini dirumuskan sebagai berikut:

$$
\begin{aligned}
& D L n P D B_{t}=\beta_{0}+\beta_{1} D L n P E M_{t}+\beta_{2} D L n S B I S_{t}+\beta_{3} D L n E X_{t}+\beta_{4} L_{n P E M_{t-1}}+\beta_{5} L_{n} S B I S_{t} \\
& { }_{1}+\beta_{6} L n E X_{t-1}+\beta_{7} E C T \\
& \text { Di mana: } \\
& \beta_{0} \quad=\text { Konstanta } \\
& \beta_{1-} \beta_{6} \quad=\text { Koefisien regresi } \\
& \beta_{7} \quad=\text { Koefisien ECT } \\
& \text { DLnPDB }_{\mathrm{t}}=\text { Perubahan PDB periode } \mathrm{t} \\
& \text { DLnPEM }_{\mathrm{t}}=\text { Total pembiayaan bank syariah (jangka pendek) } \\
& \text { DLnSBIS }_{\mathrm{t}}=\text { Sertifikat Bank Indonesia Syariah (jangka pendek) } \\
& \text { DLnEX }_{\mathrm{t}}=\text { Kontribusi ekspor (jangka pendek) } \\
& \text { LnPEM }_{\mathrm{t}-1} \quad=\text { Total pembiayaan bank syariah (jangka panjang) } \\
& \text { LnSBIS }_{\mathrm{t}-1}=\text { Sertifikat Bank Indonesia Syariah (jangka panjang) } \\
& \operatorname{LnEX}_{\mathrm{t}-1} \quad=\text { Kontribusi ekspor (jangka panjang) } \\
& \text { ECT = Error Correction Term (koreksi kesalahan) }
\end{aligned}
$$

\section{Analisis dan Interpretasi}

Pengujian terhadap keberadaan unit root untuk semua variabel yang dimasukkan dalam model menunjukkan bahwa pada tingkat level hanya variabel

\footnotetext{
${ }^{9}$ Nachrowi D dan Hardius Usman, Penggunaan Teknik Ekonometri, h. 367.

${ }^{10}$ Insukindro, Ekonomi Uang dan Bank, (Yogyakarta: BPFE UGM,1993).
} 
SBIS saja yang terbebas dari unit root sedangkan variabel lainnya mempunyai unot root. Hal ini ditunjukkan oleh nilai ADF statistik yang lebih besar dari nilai kritis Mac Kinnon dengan tingkat signifikansi 5\% (Tabel 1). Dapat dikatakan bahwa pada tingkat level hanya variabel SBIS yang stasioner. Oleh karenanya, pengujian unit root dilakukan pada tingkat First Difference. Hasil dari pengujian menunjukkan bahwa semua variabel terbebas dari unit root, artinya bahwa semua data telah stasioner pada ordo yang sama di tingkat first difference (Tabel 2).

Tabel 1: Hasil Uji ADF Test pada Tingkat Level

\begin{tabular}{cccc}
\hline \multirow{2}{*}{ Variabel } & \multicolumn{2}{c}{ Level } & \multirow{2}{*}{ Keterangan } \\
\cline { 2 - 3 } & ADF Value & Nilai Kritis 5\% & \\
\hline LnPDB & $-0,765016$ & $-2,917650$ & Tidak Stasioner \\
\hline LnPEM & $-0,097496$ & $-2,918778$ & Tidak Stasioner \\
\hline LnSBIS & $-4,403722$ & $-2,919952$ & Stasioner \\
\hline LnEX & $-1,151299$ & $-2,918778$ & Tidak Stasioner \\
\hline \multicolumn{3}{c}{ Sumber: Eviews 6.0 (data diolah) }
\end{tabular}

Tabel 2: Hasil Uji ADF Test pada Tingkat First Difference

\begin{tabular}{cccc}
\hline \multirow{2}{*}{ Variabel } & \multicolumn{2}{c}{ First Difference } & \multirow{2}{*}{ Keterangan } \\
\cline { 2 - 3 } & ADF Value & Nilai Kritis 5\% & \\
\hline LnPDB & $-6,741007$ & $-3,498692$ & Stasioner \\
\hline LnPEM & $-10,64438$ & $-3,498692$ & Stasioner \\
\hline LnSBIS & $-5,619492$ & $-3,498692$ & Stasioner \\
\hline LnEX & $-11,09896$ & $-3,498692$ & Stasioner \\
\hline
\end{tabular}

Sumber: Eviews 6.0 (data diolah)

Selanjutnya pengujian terhadap ada tidaknya kointegrasi diantara variabelvariabel, hasil estimasi menunjukkan bahwa nilai t-statistik ADF lebih besar dari nilai kritis 5\% maka residual dari persamaan telah stasioner pada derajat integrasi nol atau I(0), sehingga variabel-variabel tersebut dapat dikatakan terkointegrasi atau terdapat indikasi hubungan jangka panjang (Tabel 3).

Tabel 3: Hasil Uji Kointegrasi

\begin{tabular}{lll}
\hline \hline & t-Statistic & Prob.* \\
\hline \hline
\end{tabular}




\begin{tabular}{lccc} 
Augmented Dickey-Fuller test statistic & -4.333270 & 0.0000 \\
\hline Test critical values: & $1 \%$ level & -2.609324 & \\
& $5 \%$ level & -1.947119 & \\
& $10 \%$ level & -1.612867 & \\
\hline \hline
\end{tabular}

Sumber: Eviews 6.0

Adanya indikasi hubungan keseimbangan dalam jangka panjang belum dapat digunakan sebagai bukti bahwa terdapat hubungan jangka pendek. Sehingga untuk mengetahui itu harus diuji Error Correction Model (ECM). ECM merupakan salah satu pendekatan untuk menganalisis model time series yang digunakan untuk melihat konsistensi antara hubungan jangka pendek dengan hubungan jangka panjang dari variabel-variabel yang diuji. Untuk menyatakan apakah model yang digunakan benar atau tidak maka koefisien error correction term (ECT) harus signifikan.

Hasil pengolahan data yang dilakukan dengan menggunakan program komputer EViews 6.0, dengan model regresi linier ECM ditampilkan sebagai berikut:

\section{Tabel 4 : Hasil Uji ECM}

Dependent Variable: D(LNPDB)

Method: Least Squares

Date: 04/19/12 Time: 21:30

Sample (adjusted): 2007M02 2011M06

Included observations: 53 after adjustments

\begin{tabular}{cccrr}
\hline \hline Variable & Coefficient & Std. Error & t-Statistic & \multicolumn{1}{c}{ Prob. } \\
\hline \hline C & 6.685072 & 1.951061 & 3.426378 & 0.0013 \\
D(LNPEM) & 0.062868 & 0.033225 & 1.892174 & 0.0649 \\
D(LNSBIS) & -0.014490 & 0.003552 & -4.079470 & 0.0002 \\
D(LNEX) & 0.004867 & 0.015234 & 0.319478 & 0.7508 \\
LNPEM(-1) & -0.333613 & 0.098763 & -3.377903 & 0.0015 \\
LNSBIS(-1) & -0.414102 & 0.121811 & -3.399530 & 0.0014 \\
LNEX(-1) & -0.417637 & 0.121723 & -3.431053 & 0.0013 \\
ECT & 0.409174 & 0.120190 & 3.404387 & 0.0014 \\
\hline \hline R-squared & 0.395242 & Mean dependent var & 0.004824 \\
Adjusted R-squared & 0.301169 & S.D. dependent var & 0.011010 \\
S.E. of regression & 0.009204 & Akaike info criterion & -6.400066 \\
Sum squared resid & 0.003812 & Schwarz criterion & -6.102663 \\
Log likelihood & 177.6017 & Hannan-Quinn criter. & -6.285699
\end{tabular}




\begin{tabular}{llll} 
F-statistic & 4.201424 & Durbin-Watson stat & 2.204713 \\
Prob(F-statistic) & 0.001227 & \\
\hline \hline
\end{tabular}

Sumber: Eviews 6.0

Berdasarkan tabel di atas, maka model hasil regresi ECM dalam jangka pendek dan panjang adalah sebagai berikut:

$$
\begin{aligned}
& L_{n P D B_{t}}=6,685072+0,062868^{*} D L n P E M_{t}-0,014490^{*} D L n S B I S_{t}-0,004867^{*} D L n E X_{t}- \\
& 0,333613 * \mathrm{LnPEM}_{t-1}-0,414102 * \mathrm{LnSBIS}_{t-1}-0,41763{ }^{*} \mathrm{LnEX}_{t-1}+0,409174 * E C T
\end{aligned}
$$

Interpretasi terkait model ECM di atas, bahwa model spesifikasi yang digunakan dalam penelitian telah sahih (valid). Ini dapat dilihaat dari koefisien ECT yang bernilai positif dan nilainya berada diantara 0 dan 1 yaitu 0,409174 serta nilai probabilitasnya yang lebih kecil dari 0,05 yaitu 0,0014. Lebih lanjut, nilai Adjusted $\mathrm{R}^{2}$ yang ditemukan dalam hasil uji ECM di atas adalah sebesar 0,301169. Ini berarti bahwa $30 \%$ variabel pertumbuhan ekonomi dapat dijelaskan oleh variasi variabel bebasnya, sedangkan sisanya $70 \%$ dijelaskan oleh variasi variabel lain di luar model yang tidak diikutsertakan dalam penelitian ini.

Intepretasi dari hasil estimasi jangka pendek Model ECM adalah sebagai berikut: Pertama, hasil perhitungan menunjukkan bahwa koefisien regresi variabel total pembiayaan bank syariah dalam jangka pendek (DLnPEM) tidak berpengaruh secara signifikan terhadap pertumbuhan ekonomi. Pada tabel 4.10 dapat dilihat tingkat probabilitasnya yaitu sebesar 0.0649 , yang lebih besar dibandingkan dengan tingkat signifikansi 5\% dan nilai koefisien sebesar 0,062868. Sehingga dapat disimpulkan bahwa berapapun kenaikan jumlah total pembiayaan bank syariah tidak akan berpengaruh apa-apa dalam jangka pendek terhadap pertumbuhan ekonomi di Indonesia.

Kedua, D(LnSBIS) menunjukkan nilai probabilitas sebesar 0,0002. Artinya, variabel SBIS berpengaruh signifikan terhadap pertumbuhan ekonomi dalam jangka pendek dengan tingkat signifikansi 5\% sedangkan koefisiennya sebesar 0,014490. Dapat disimpulkan bahwa jika SBIS naik sebesar 1 persen maka pertumbuhan ekonomi akan mengalami penurunan sebesar 0,014490 persen. Hal ini sesuai dengan penelitian yang dilakukan oleh Yunie Fitriani (2011)yang menyatakan bahwa dalam jangka pendek SBIS berpengaruh negatif terhadap pertumbuhan ekonomi.

Kedua, hasil perhitungan menunjukkan bahwa variabel Ekspor dalam jangka pendek (DLNEX) tidak berpengaruh secara signifikan terhadap pertumbuhan ekonomi. Hal ini dapat dilihat dari tabel 4.10 yang menunjukkan tingkat 
probabilitasnya sebesar 0.7508 yang lebih besar bila dibandingkan dengan tingkat signifikansi 5\% dan nilai koefisien sebesar 0,004867. Artinya, berapapun kenaikan jumlah ekspor yang terjadi tidak akan berpengaruh terhadap pertumbuhan ekonomi dalam jangka pendek.

Intepretasi dari hasil estimasi jangka pendek Model ECM adalah sebagai berikut: Pertama, dalam jangka panjang variabel total pembiayaan bank syariah (LNPEM (-1)) berpengaruh secara signifikan terhadap pertumbuhan ekonomi. Pada tabel 4.10 dapat dilihat tingkat probabilitasnya sebesar 0.0015 dengan koefisien jangka panjangnya sebesar -0,333613 yang berarti jika total pembiayaan bank syariah naik sebesar 1 persen, maka pertumbuhan ekonomi akan mengalami penurunan sebesar 0,33613 persen.

Kedua, dalam jangka panjang variabel SBIS (LnSBIS (-1)) berpengaruh secara signifikan terhadap pertumbuhan ekonomi. Pada tabel 4.10 menunjukkan tingkat probabilitas sebesar 0,0014 lebih kecil dari tingkat signifikansi 5\% dan nilai koefisiennya sebesar -0,414102. Artinya, jika SBIS naik sebesar 1\% maka pertumbuhan ekonomi akan mengalami penurunan sebesar 0,414102 persen.

Ketiga, dalam jangka panjang variabel ekspor (LnEX (-1)) berpengaruh negatif secara signifikan terhadap pertumbuhan ekonomi. Tabel 4.10 menunjukkan tingkat probabilitas ekspor sebesar 0,0013 yang lebih kecil dari tingkat signifikansi 5\% dan nilai koefisiennya sebesar -0,417637. Artinya, ketika terjadi kenaikan volume ekspor 1 persen maka pertumbuhan ekonomi akan mengalami penurunan sebesar 0,417637 persen.

Telah dipaparkan sebelumnya bahwa pembiayaan bank syariah dalam jangka pendek tidak berpengaruh signifikan terhadap pertumbuhan ekonomi sedangkan dalam jangka panjang berpengaruh negatif terhadap pertumbuhan ekonomi. Hal ini bertentangan dengan yang seharusnya, karena pada dasarnya pembiayaan yang dilakukan oleh bank syariah langsung ke sektor riil. Namun, faktanya saat ini market share perbankan syariah masih sangat kecil, yaitu 3,2 \% belum bisa bersaing dengan bank konvensional yang telah berdiri lebih lama dari bank syariah. Selain itu, masih mendominasinya produk murâbahah di bank syariah daripada produk kerja sama, mudhârabah dan musyârakah. Per Desember 2011, porsi pembiayaan murâbahah dalam penyaluran pembiayaan bank syariah sebesar 54,06\%, sedangkan mudhârabah dan musyârakah sebesar 29,31\%.

Inilah yang menyebabkan pembiayaan bank syariah dalam jangka panjang berpengaruh negatif. Tingginya pembiayaan murabahah akan membuat masyarakat lebih konsumtif. Lain halnya dengan pembiayaan mudahrabah dan musyârakah yang menunjukkan adanya aktivitas usaha yang dilakukan, sehingga me- 
ningkatkan produktivitas masyarakat yang akhirnya akan menaikkan pendapatan masyarakat. Ketika pendapatan masyarakat naik dan stabil akan meningkatkan tingkat konsumsi masyarakat dan mendorong pertumbuhan industri dalam menciptakan barang dan jasa. Hal ini berlangsung secara berkelanjutan, karena masyarakat mempunyai aktivitas usaha dari pembiayaan mudhârabah dan musyârakah yang akhirnya akan menaikkan pendapatan nasional dan pertumbuhan ekonomi.

Hal ini sesuai dengan penelitian yang dilakukan oleh Mawaddah (2011) yang menyatakan bahwa pembiayaan mudhârabah berpengaruh positif terhadap pertumbuhan ekonomi dalam jangka panjang. Selain itu, hal lain yang perlu diperhatikan juga oleh perbankan syariah bahwa dari hasil regresi ECM diketahui bahwa SBIS memberikan pengaruh negatif terhadap pertumbuhan ekonomi baik dalam jangka pendek maupun jangka panjang. Dampak negatif ini mencerminkan karakteristik SBIS yang menyerap dana perbankan sehingga tidak tersalurkan ke sektor riil. Keberadaan instrumen ini hendaknya disikapi dengan bijak oleh perbankan syariah, agar dana-dana yang disimpan pada instrumen ini tidak terlalu banyak dan lebih memilih untuk menyalurkannya pada pembiayaan yang memberikan efek ganda baik terhadap masyarakat secara langsung maupun terhadap perekonomian secara umum.

Dari hasil regresi ECM menunjukkan bahwa dalam jangka pendek ekspor tidak berpengaruh terhadap pertumbuhan ekonomi, sedangkan dalam jangka panjang ekspor memberikan pengaruh negatif terhadap pertumbuhan ekonomi. Hal ini bertentangan dengan teori-teori yang dikemukakan sebelumnya oleh para ahli ekonomi yang menyatakan bahwa dengan perdagangan luar negeri atau kegiatan ekspor akan meningkatkan pendapatan nasional yang secara tidak langsung akan meningkatkan pertumbuhan ekonomi.

Penyebab dari negatifnya pengaruh yang diberikan kegiatan ekspor terhadap pertumbuhan ekonomi adalah bahwa saat ini Indonesia lebih banyak melakukan ekspor dengan kondisi barang yang diekspor adalah barang mentah, bukan barang setengah jadi atau bahkan barang jadi. Ketika barang yang diekspor adalah barang mentah maka pendapatan yang dihasilkan jauh lebih sedikit jika barang yang diekspor merupakan barang setengah jadi yang telah diberikan nilai tambah (value added) terhadap barang tersebut.

Data Laporan Perekonomian Indonesia Tahun 2010 menyebutkan bahwa volume ekspor non migas tertinggi terjadi pada komoditas pertambangan, sekitar $30 \%$, sementara komoditas industri dan pertanian, tumbuh lebih rendah, masingmasing $2 \%$ dan $13,6 \%$. Secara komoditas, pertumbuhan ekspor pertambangan 
terutama terjadi pada nikel, aluminium dan batubara. Inilah yang menyebabkan pengaruh ekspor Indonesia berpengaruh negatif. Ekspor barang lebih banyak terjadi adalah komoditas ekspor yang berbasis Sumber Daya Alam (SDA) bukan pada komoditas yang berbasis olahan baik industri ataupun manufaktur. Hal ini menjadi lebih ironi ketika barang mentah yang telah diekspor ke luar negeri, oleh negara lain akan diproduksi dan dihasilkan barang jadi yang nantinya akan diimpor oleh industri usaha dalam negeri dengan harga yang jauh lebih mahal dan selisih jumlah yang dikeluarkan lebih banyak dibandingkan pendapatan yang diterima dari hasil ekspor barang mentah.

\section{Penutup}

Dari hasil penelitian mengenai faktor-faktor yang memengaruhi pertumbuhan ekonomi di Indonesia, maka dapat ditarik kesimpulan bahwa dalam jangka pendek, total pembiayaan bank syariah dan kontribusi ekspor tidak memengaruhi secara signifikan terhadap pertumbuhan ekonomi, sementara Sertifikat Bank Indonesia Syariah (SBIS) berpengaruh negatif secara signifikan terhadap pertumbuhan ekonomi pada periode 2007-2011. Sedangkan dalam jangka panjang ketiga variabel independent (total pembiayaan bank syariah,SBIS, dan kontribusi ekspor) berpengaruh negatif secara signifikan terhadap pertumbuhan ekonomi pada periode 2007-2011. []

\section{Pustaka Acuan}

'Ayuniyya, Qurroh dkk, "Pengaruh Instrumen Moneter dan Konvensional", dalam Jurnal Iqtishodia, Institut Pertanian Bogor, 2010.

Asnawi, "Pengeluaran Pembangunan, Penanaman modal, Ekspor dan Pertumbuhan Ekonomi di Provinsi Aceh", Aceh Development International Conference (ADIC), 2011.

Beik, Irfan Syauqi, "Karakter Keuangan Syariah", dalam Tsaqofi Jurnal Iqtishodia, Institut Pertanian Bogor, 2010.

Boediono, Teori Pertumbuhan Ekonomi: Seri Sinopsis Pengantar Ilmu Ekonomi No. 4, Yogyakarta: BPFE, 1993.

Chouwdury, Mausudul Alam, Money in Islam, London: Routledge,1997.

Insukindro, Ekonomi Uang dan Bank, Yogyakarta: BPFE UGM, 1993.

Karim, Adiwarman A., Ekonomi Islam Suatu Kajian Ekonomi Makro, Jakarta: The International Institute of Islamic Thought Indonesia, 2002.

Murni, Asfia, Ekonomika Makro, Bandung: PT. Refika Aditama, 2006. 
Nachrowi, Nachrowi D dan Hardius Usman, Penggunaan Teknik Ekonometri, Jakarta: PT. Raja Grafindo Persada, 2006.

Titman dan Warga, "Stoct Return As Predictors of Interest Rates and Inflation", dalam Journal of Financial and Quanittive Analysis, Vol. 24, 1989. 